\title{
Forum
}

\section{Will alleviating poverty solve the bushmeat crisis?}

\author{
John G. Robinson and Elizabeth L. Bennett
}

There is a broad consensus among the scientific and conservation communities that the 'bushmeat crisis' in tropical forests is not hyperbole. The annual harvest of wild species for their meat is vast: estimates are 23,500 tonnes in Sarawak (Bennett, 2002), 67,000-164,000 tonnes in the Brazilian Amazon (Robinson \& Redford, 1991), and 1-5 million tonnes in Central Africa (Wilkie \& Carpenter, 1999; Fa \& Peres, 2001). Hunting rates exceed sustainable levels across large swathes of the tropics, and as a consequence populations of hundreds of species are going locally extinct. In addition, people whose lives depend on wildlife are losing a significant natural resource. Across the humid tropics millions of people depend on meat from wildlife for both food and income. For many of the poorest rural people bushmeat is not a luxury or something that they only turn to in times of hardship. It is a vital source of animal protein, and a commodity that can be sold.

The twin imperatives of addressing people's needs and aspirations on the one hand, and conserving the world's species on the other, has suggested to many a 'silver bullet': solve the bushmeat crisis by alleviating poverty in tropical countries. The logic from the perspective of London or Washington is unassailable: poor countries and people are trapped by their immediate needs, and forced by circumstances to overuse their resources. Raising people's incomes by providing alternative sources of revenue will therefore lower harvest rates of natural resources.

But will poverty alleviation solve the bushmeat crisis? The history of development assistance from the 1950s onwards is not encouraging, having fostered environmental degradation and resource depletion in less developed countries. The impact of poverty alleviation efforts on wildlife harvests will ultimately depend on how aid is targeted and which people benefit.

If wildlife harvests are to decrease to sustainable levels the people whose behaviour must change are those who hunt and possibly sell wildlife, and those who buy it. Those who hunt are the millions of people at the margins of the cash economy in Asia, Africa and Latin America, and whose lives are intertwined with natural areas. These are the people who live on less than US \$1 per day. Despite rhetoric to the contrary, development assistance has traditionally failed to cater

John G. Robinson (Corresponding author) and Elizabeth L. Bennett Wildlife Conservation Society, 2300 Southern Blvd., Bronx, New York 10460, USA.F-mail:wildcons@aol.com

Manuscript accepted for publication 3 August 2002. for the needs of these people. They typically lack the education, skills and cultural context to take advantage of cash-earning jobs in plantations and industry. International assistance has tended to work against these most marginalized of people. They lose access to their land and traditional resources, often experiencing drops in daily protein consumption, as development initiatives open up their lands to outsiders. Lacking capital and access to markets, such people cannot switch to alternative livelihoods or food sources. Hit by the advancing development frontier and the need to engage with a cash economy, they often sell wildlife as a principal source of income. This harvest is rarely sustainable, exacerbating their problem. Sustainable livelihoods for these people become a chimera.

Development assistance has also been counterproductive to the goal of changing the behaviour of wild meat purchasers. Development efforts have tended to focus on creating jobs for the urban and semi-urban poor: people with some education who can benefit from the newly created jobs. Experience from Africa and Asia has shown that as wealth increases so does the demand for wildlife; the expanding wildlife markets in towns and cities from Libreville and Brazzaville to Bangkok, Jakarta and Shanghai epitomize this.

Historical failure does not doom future efforts. Development assistance undoubtedly has a role to play in solving the bushmeat crisis, but simplistic efforts to create jobs and increase national GDP will surely have all the expected tragic consequences. The only way out of this crisis will be offered by long-term, integrated efforts that provide alternative sources of protein and income for the rural poor, curtail the commercial trade in wildlife, secure wildlife populations in protected areas, educate hunters and buyers, and involve government, the not-for-profit and the private sectors. Unfortunately there is no 'silver bullet' for the twin goals of conserving wildlife across the humid tropics and preventing the people whose lives now depend on wildlife from being driven further against the wall.

\section{References}

Bennett, E.L. (2002) Is there a link between wild meat and food security? Conservation Biology, 16, 590-592.

Fa, J.E. \& Peres, C. (2001) Hunting in tropical forests. In Conservation of Exploited Species (eds J.D. Reynolds, G.M. Mace, K.H. Redford \& J.G. Robinson), pp. 203-241. Cambridge University Press, Cambridge, UK.

Robinson, J.G. \& Redford, K.H. (1991) Neotropical Wildlife Use and Conservation. Chicago University Press, Chicago, USA. 